\title{
Growth, Carbon Acquisition, and Source-Sink Relationships in 'Titan' Red Raspberry
}

\author{
Gina E. Fernandez and Marvin P. Pritts ${ }^{1}$ \\ Department of Fruit and Vegetable Science, Cornell University, Ithaca, NY 14853 \\ Additional index words. Rubus, growth analysis, photosynthesis
}

\begin{abstract}
Seasonal changes in growth, mean maximal photosynthetic rates, and the temperature and light response curves of 'Titan' red raspberry (Rubus idaeus $\mathrm{L}$.) were obtained from potted plants grown under field conditions. Primocane dry weight accumulation increased steadily at the beginning and the end of the season, but growth slowed midseason during fruiting. The slower midseason dry-weight accumulation rate coincided with an increase in root dry weight. Primocane net assimilation rate (NAR) was highest early in the season. Floricane photosynthetic rates (A) were highest during the fruiting period, while primocane A remained steady throughout the season. Primocane and floricane leaflets displayed a midday depression in A under field conditions, with a partial recovery in the late afternoon. Photosynthetic rates of primocane and floricane leaves were very sensitive to temperature, exhibiting a decline from 15 to $40 \mathrm{C}$. Light-response curves differed depending on cane type and time of year. A temporal convergence of sink demand from fruit, primocanes, and roots occurs when plants experience high temperatures. These factors may account for low red raspberry yield.
\end{abstract}

Quantifying plant growth is an essential first step in developing cultural practices that increase yield in crop plants (Gutschick, 1987). Furthermore, quantifying photosynthetic responses, Callocation patterns, and source-sink relationships contributes to understanding plant growth and yield potential. Considerable effort has been expended to obtain these data for most agronomic and horticultural crops. Such data, although important, have not been obtained for raspberries, despite their prominence as a high-value fruit crop.

Interpreting plant growth data can be difficult because various plant parts have multiple functions that change over time. For example, leaves support vegetative growth early in the season and fruit growth later in the season. Clear differences in physiology and $\mathrm{C}$ allocation have been observed for vegetative and reproductive structures in cultivated (Forshey and Elfving, 1989; Fujii and Kennedy, 1985; Wright, 1989) and wild plants (Dawson and Bliss, 1993; Watson, 1984). Rubus sp., including raspberry, provide a unique model system for studying relationships among vegetative and fruiting structures in perennial crops. A raspberry plant produces canes that grow vegetatively for 1 year and flower, fruit, and senesce the following year. While the second year canes are fruiting (floricanes), new vegetative canes (primocanes) are produced from the same underground crown and root system. This distinct separation of vegetative and reproductive function allows one to study source-sink relationships without the level of confounding often encountered with other crops in which shoots have dual functions.

Many have tried to improve raspberry yield without knowledge of the plant's basic physiology. For example, short-term yield has been increased by removing emerging primocanes (Freeman et al., 1989; Lawson and Wiseman, 1983; Nehrbas and Pritts, 1988). Whether this is caused by eliminating competing sinks or improved light interception of floricanes is unknown. Pruning and

Received for publication 24 Jan. 1994. Accepted for publication 6 June 1994. We gratefully acknowledge the technical assistance of Caitlan Morse, Todd Dawson, MaryJo Kelly, and Liora Kahn. We thank Scott Cameron, Todd Dawson, and Tom Whitlow for their critical review of the manuscript. The cost of publishing this paper was defrayed in part by the payment of page charges. Under postal regulations, this paper therefore must be hereby marked advertisement solely to indicate this fact.

${ }^{1}$ Dept. of Fruit and Vegetable Science Paper no. 47. Supported by Hatch Project NY 142-402. trellising recommendations have been developed by trial and error, without understanding the response that raspberry plants show to altered light and temperature or understanding which components of the plant function as $\mathrm{C}$ sources or sinks.

Quantifying seasonal changes in $\mathrm{C}$ acquisition and allocation and plant growth should enhance our understanding of why certain cultural practices are successful and suggest other approaches that may improve long-term productivity. The objectives of this research were to 1) form a detailed growth analysis of the seasonal changes of dry-matter growth and partitioning between primocanes, floricanes, and roots; 2) document seasonal changes in $\mathrm{C}$ assimilation rates for both cane types; and 3) quantify seasonal changes in net photosynthetic rates in response to changing light and temperature using field-grown plants.

\section{Materials and Methods}

Growth analysis. 'Titan' red raspberry is a crown-forming, high-yielding, widely planted cultivar adapted to New York conditions (Sanford et al., 1985). On 17 May 1991, tissue-cultured plugs of 'Titan' were planted in 25-liter (0.40-m-i.d.) pots. The potting medium consisted of 2 montmorillomite-illite baked clay $: 1$ no. 4 coarse sand (by volume). The plants were grown outdoors for two growing seasons at the Cornell Univ. Orchards, Ithaca, N.Y., in 10-m rows. Irrigation and fertilization were supplied using a trickle system with a constant feed of 75 to $100 \mathrm{ppm} \mathrm{N}$ with Peters 20-20-20 soluble fertilizer (W.R. Grace \& Co., Fogelsville, Pa.) alternated with water as needed. The potted plants were overwintered in a soil trench and covered with straw mulch.

In 1992, the plants were pruned to two floricanes per pot. Floricanes were pruned to a height of $1.0 \mathrm{~m}$ and tied to a V-trellis with a maximum spread of $70 \mathrm{~cm}$ at $1.0 \mathrm{~m}$ from the soil level. Eight randomly selected plants were harvested on each of nine dates from late April to late September 1992. The plants spanned the growth stages from dormancy to senescence of most floricane leaves. At each harvest date, plants were divided into primocanes, floricanes, and roots. Dry weight of all leaves, canes, and roots and number of nodes were recorded. Leaf area for the first three primocanes to emerge and three randomly selected floricane laterals from each of the two floricanes were collected and used to estimate leaf areas for entire canes based on the dry weight and leaf area relationship. Leaf areas were measured using a leaf area meter 
(LI-3000; LI-COR, Lincoln, Neb.). Fruit fresh and dry weights were recorded at each whole-plant harvest and twice weekly during the harvest period.

Relative growth rate (RGR) and net assimilation rate (NAR) were calculated using the classical approach in which mean values of the parameters were measured at each harvest, based on changes over a number of days, from calculations described in Chiariello et al. (1991). Growth parameters were calculated from changes in values between successive harvests and based on leaf areas and dry weights of floricanes, primocanes, and roots, independently. However, to standardize information for a variety of climates, seasonal changes in dry weight $(\mathrm{g})$, RGR $\left(\mathrm{g} \cdot \mathrm{g}^{-1} \cdot \mathrm{day}^{-1}\right)$, and NAR $\left(\mathrm{g} \cdot \mathrm{m}^{-2} \cdot \mathrm{day}^{-1}\right)$ were reported as a function of growing degree-day (GDD) accumulations (base $50 \mathrm{~F}$ ); i.e., for each whole-plant harvest date, values were reported according to their corresponding GDD.

Field gas exchange. Plant material was treated as above. Net photosynthetic rates $(\mathrm{A})$ were obtained using a portable closed gasexchange system (LI-6200; LI-COR). All rates, except diurnal measurements, were taken $\approx 3$ to $5 \mathrm{~h}$ after sunrise on seven dates during the 1992 growing season, within 1 day of whole-plant harvest, on a group of eight plants reserved for gas exchange. One recently expanded primocane leaf and a floricane leaf exposed to full sun were used on each of the eight plants for gas-exchange measurements. All measurements were made on warm (15 to 25C), sunny days (photosynthetically active radiation 1200 to $1500 \mu \mathrm{mol} \cdot \mathrm{m}^{-2} \cdot \mathrm{s}^{-1}$ ). Diurnal measurements were taken from $\approx 0.5$ to $14 \mathrm{~h}$ after sunrise (700 and $2000 \mathrm{HR}$ ) in June 1992.

Steady-state gas exchange. Plant material and growing conditions were identical to the above experiment except transplants were set on 20 July 1990, overwintered in the ground in 1990-91 and 1991-92, and pruned to two floricanes in Spring 1991, 1992, and 1993. Plants were allowed to acclimate to laboratory conditions at least $1 \mathrm{~h}$ before measurements were taken.

Steady-state gas-exchange measurements were made in July (1295 to 1374 GDD) and August (1815 to 1942 GDD) 1993 during and after the harvest period, respectively, using an open gasexchange system (model MPH-1000; Campbell Scientific, Logan, Utah) and following methods described by Dawson and Geber (1995). Three potted plants that had primocanes and floricanes were used for each set of measurements. For light-response curves, a series of neutral-density filters were sequentially placed above the leaf in the cuvette allowing for full light saturation of $\approx 1400$ photosynthetic photon flux (PPF) and gradually lowered seven levels with the filters to low light conditions (0 to 10 PPF). A 1000$\mathrm{W}$ high-pressure sodium lamp, was used as the light source. A water filter was placed between the light source and the leaf cuvette to remove excess infrared radiation. This did not alter light quality or quantity (Dawson and Geber, 1995). Temperature, dewpoint, and $\mathrm{CO}_{2}$ concentration within the cuvette were maintained at $25 \mathrm{C}$, $15 \mathrm{C}$, and $350 \mathrm{ppm}$, respectively. The dewpoint was set at 10C to avoid condensation when the chamber temperature dropped to $15 \mathrm{C}$. Each shade treatment was imposed $\approx 15$ min before a measurement was taken. For temperature-response curves, the temperature in the cuvette was changed in $3 \mathrm{C}$ increments and the leaf was allowed to acclimate to each treatment for $\approx 15 \mathrm{~min}$ before a measurement was taken.

\section{Results and Discussion}

Growth analysis. A growth curve constructed for primocanes, floricanes, roots, and fruit indicated that dry weight accumulation of these plant parts differed during the growing season (Fig. 1A). Floricanes exhibited a slight gain in dry weight up to 375 GDD (full bloom) and did not exhibit any other significant change in dry weight until the end of the season, when a second flush of lateral branches emerged from previously dormant buds. This second flush of laterals was not expected. Potted raspberry plants may exhibit this phenomenon or late bud break could have been the result of excessive rain in 1992. Late budbreak has not been observed in 'Titan' in the field.

Primocane dry-weight accumulation increased steadily up to the peak fruiting period, leveled, and then increased again after the harvest period (Fig. 1A). The decline in primocane dry weight during fruiting could be due to the movement of carbohydrates into the fruit and away from primocane apices. However, other possible explanations exist. In a Minnesota study, high temperatures, drought, and high winds during summer were thought to reduce primocane growth (Brierley, 1931). In our study, root dry weight increased significantly during the onset of fruiting and then decreased. Roots, in addition to fruit, could be competitive sinks for carbohydrates, since organs with high growth rates may compete for a limited supply of photosynthate (Sterck and Ubysz, 1974). Vorocihinia (1967) found that, in red raspberry, root growth coincided with a period of slower shoot growth and that an inverse relationship existed between root growth and yield. In another study in which raspberry leaves were labeled with ${ }^{14} \mathrm{CO}_{2}$, autoradiography indicated that roots were a competing sink for primocane photosynthates when primocane dry-weight accumulation slowed and root dry weight increased (Fernandez and Pritts, 1993). These possible changes in sink demand are reflected in changes in RGR (Table 1). Floricane RGR is greatest at the beginning of the season; primocane RGR decreases when root RGR increases.

The NAR of primocanes was negative for the first two wholeplant harvests of the season, increased for the next three harvests, peaked at $\approx 800 \mathrm{GDD}$, then declined but remained positive for the remainder of the season (Fig. $1 B$ ). Floricane NAR peaked at $\approx 300$ GDD, which coincided with the initial flush of lateral growth at the beginning of the season, while a second NAR peak occurred during fruiting (Fig. 1B). If NAR represents the efficiency of the leaf as a producer of dry weight, primocane leaves are most efficient at 400 to 850 GDD, a time that corresponds to the later stages of the first gain in primocane dry weight and a period in which light levels are increasing as primocanes begin to grow beyond the floricane canopy. A decline in NAR corresponds to a leveling of primocane dry-weight accumulation. Although new primocane leaves are continually produced during the season, leaf NAR may change over time due to altered partitioning patterns or increased internal shading. In fact, NAR may be more representative of seasonal C assimilation patterns than instantaneous gas-exchange measurements. In addition, our calculations were based on primocane dryweight accumulation only; we did not determine whether photosynthates moved to other plant parts.

Field gas exchange. In preliminary experiments, we found it difficult to collect any gas-exchange data in the early afternoon. Diurnal photosynthetic response curves indicated that floricane and primocane leaves exhibit a midday decline in A (Fig. 2). This trend has been observed in many other woody plants as well (Downton et al., 1987; Hodges, 1967; Kozlowski et al., 1991; Lakso, 1986; Landsberg et al., 1975). J.S. Cameron (personal communication) found that large amounts of starch accumulate in raspberry leaves harvested in the afternoon. This likely triggers a feedback inhibition in the photosynthetic cycle in raspberry leaves. Temperature also increases during the day and could account for some of the decrease in A if conditions become too hot. We found that stomatal conductance values displayed similar diurnal trends (data not shown), which may represent a feed-forward response 


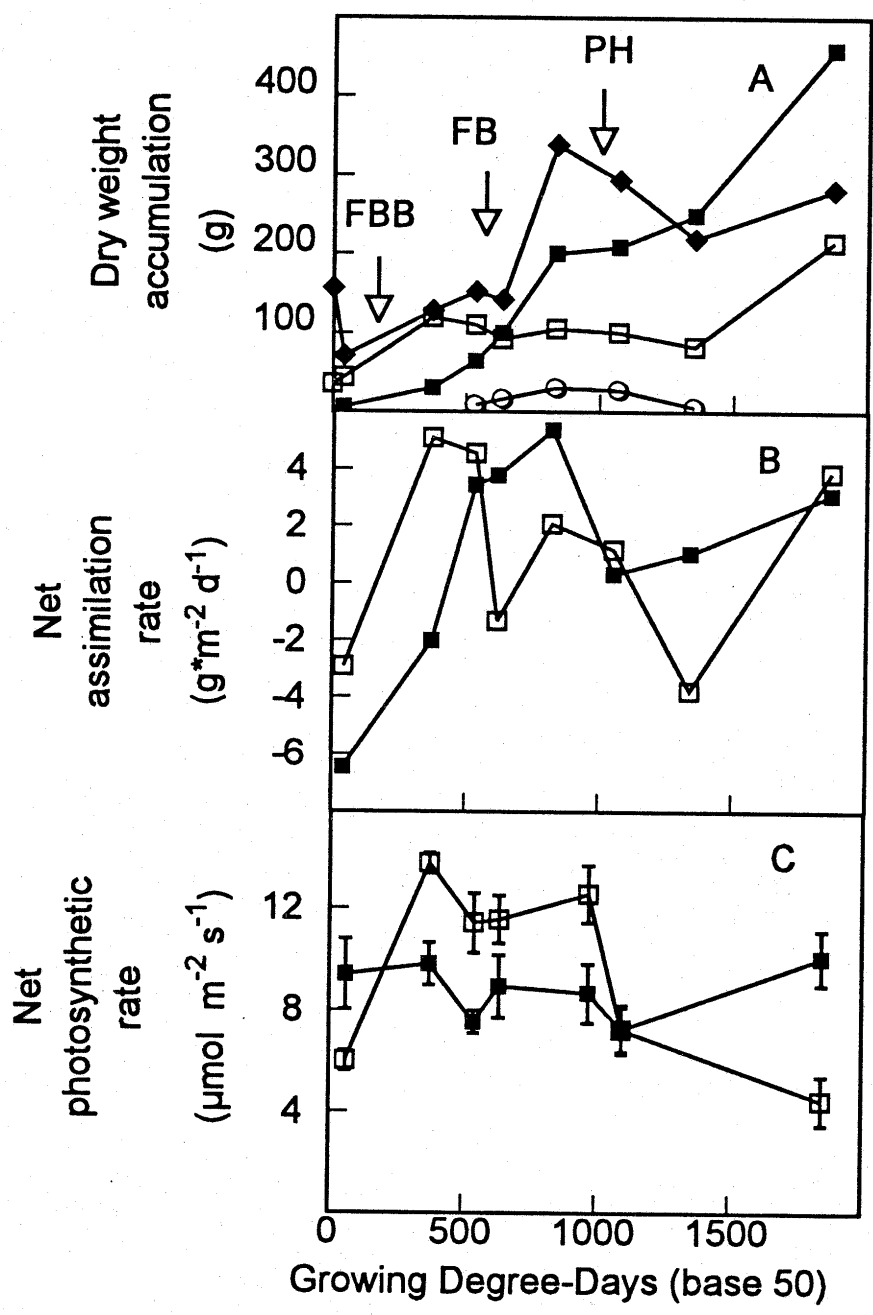

Fig. 1. Seasonal patterns of (A) dry weight accumulation of floricanes ( $\square$ ), primocanes $(\mathbf{\square})$, roots $(\bullet)$ and fruit $(O)$; $(\mathbf{B})$ net assimilation rate of floricanes $(\square)$ and primocanes $(\boldsymbol{\square})$ and $(\mathbf{C})$ net photosynthetic rate of floricanes $(\square)$ and

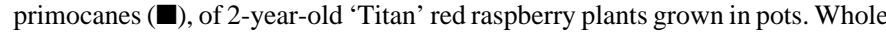
plants were harvested on eight dates during Summer 1992, Ithaca, N.Y. Phenological stages of floricane budbreak (FBB), full bloom (FB), and peak harvest $(\mathrm{PH})$ are represented by arrows in $\mathrm{A}$.

Table 1. Seasonal patterns of relative growth rate $(\mathrm{RGR})\left(\mathrm{g} \cdot \mathrm{g}^{-1} \cdot \mathrm{day}^{-1}\right) \times$ 100 of floricanes, primocanes, and roots of 'Titan' red raspberry, early, middle, and late season, based on cumulative growing degreedays(GDD) (base 50). ${ }^{\mathrm{z}}$

\begin{tabular}{lccc}
\hline \hline GDD & \multicolumn{3}{c}{ RGR } \\
\cline { 2 - 4 } (base 50 F) & Floricane $^{\mathrm{y}}$ & Primocane & Root \\
\hline $43-374$ & 32.0 & 10.9 & 2.1 \\
$636-822$ & 1.7 & 5.5 & 6.8 \\
$1354-1870$ & 1.5 & 10.9 & 0.7
\end{tabular}

${ }^{\mathrm{z}}$ Samples at each harvest $(\mathrm{n}=8)$.

yIncludes fruit weight.

that could also be responsible for the decline in A.

Mean maximum photosynthesis measurements were obtained on primocane and floricane leaves before the midday decline during the 1992 growing season (Fig. 1C). Primocane A remained steady $\left(\approx 9.0 \mu \mathrm{mol} \cdot \mathrm{m}^{-2} \cdot \mathrm{s}^{-1}\right)$ during the season, but floricane A was lower than primocane $\mathrm{A}$ at the beginning and end of the season $\left(\approx 4.0 \mu \mathrm{mol} \cdot \mathrm{m}^{-2} \cdot \mathrm{s}^{-1}\right)$. However, floricane A was higher than primocane A from 300 to 1000 GDD (Fig. 1C), coinciding with

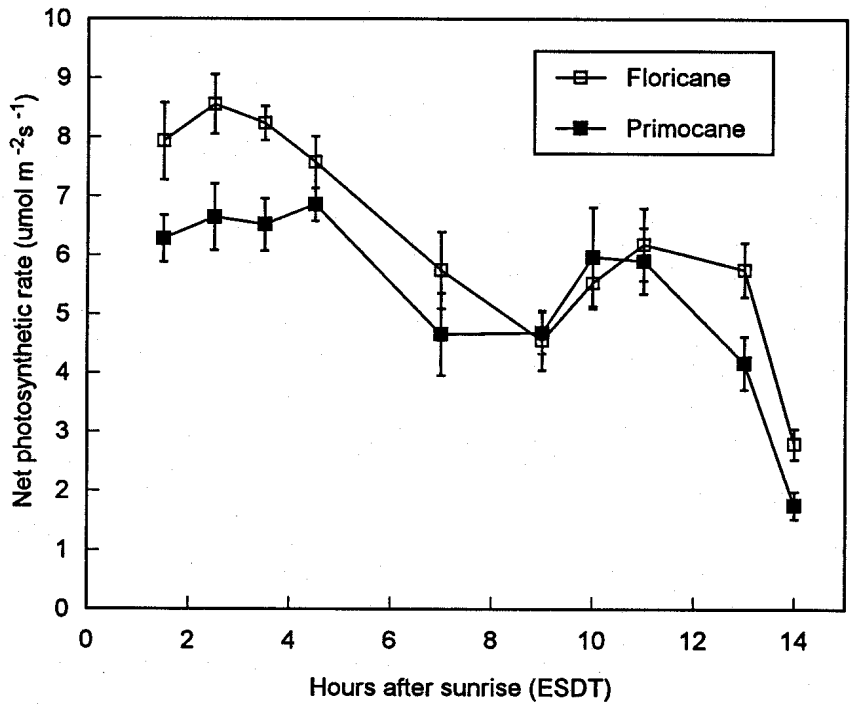

Fig. 2. Diurnal variation in net photosynthetic rate as a function of time of day under field conditions in June 1992 (605 growing degree-days). Data points represent means \pm sE of eight leaf measurements.

flowering and fruit development. Elevated A in response to the presence of sinks also has been observed in other crop plants (Avery, 1977; Chalmers et al., 1975; Dornhoff and Shibles, 1970; Flinn, 1974; Hansen, 1970). Unlike floricanes, primocane A did not seem to respond to any particular sink demand at any time during the growing season, even though vegetative growth rates varied during the season. The decline in floricane A near the end of the season may not have been due entirely to the absence of sinks, but also to leaf age. All floricane leaves emerge in the spring, so a seasonal decline in floricane A may be due to leaf senescence. Primocane A was measured on recently expanded leaves likely near their peak A.

Steady-state gas exchange. The response of floricane and primocane A to changes in light intensity were measured during fruiting (July) (1295 to 1315 GDD) and after fruiting (August) (1919 to 1942 GDD) . Light saturation levels for both primocane leaflets at both sampling dates were $\approx 500$ to 700 PPF (visual interpretation). This is consistent with the light-saturation level of other woody species (Boardman, 1977; Lakso and Seeley, 1978; Vorwinckel and Oichel, 1975).

Floricane light response of changed over the season, with floricane leaves saturating at a higher PPF and exhibiting a higher A in July than August (Fig. 3). Primocane A did not change significantly as the season progressed. This response may have been due to leaf age (Field, 1987) and consequent changes in leaf biochemical efficiency (Ball et al., 1987). As leaves age, the chloroplasts begin to break down and, consequently, electron transport and ribulose 1,5-bisphosphate regeneration capacity decline (Kutik, 1985). Additionally, rubisco activity declines in older leaves (Sestak et al., 1985). Measurements were always taken on newly expanded primocane leaflets that were being produced regularly during the growing season, while floricane leaves emerge only at the beginning of the season and start to senesce after fruiting.

The quantum yield or initial slope of the photosynthetic response curve is steeper in July (1295 to 1315 GDD) than August (1919 to 1942 GDD) for primocanes (0.0434 vs. 0.0227) and floricanes (0.0326 vs. 0.0196) (Fig. 3), a result indicating that a change occurred in the efficiency with which $\mathrm{C}$ is fixed per photon received under light-limiting conditions. Again, this is expected because older leaves have reduced light-harvesting pigments and photochemical conversion capacity (Chabot and Hicks, 1982; Field, 1987). 


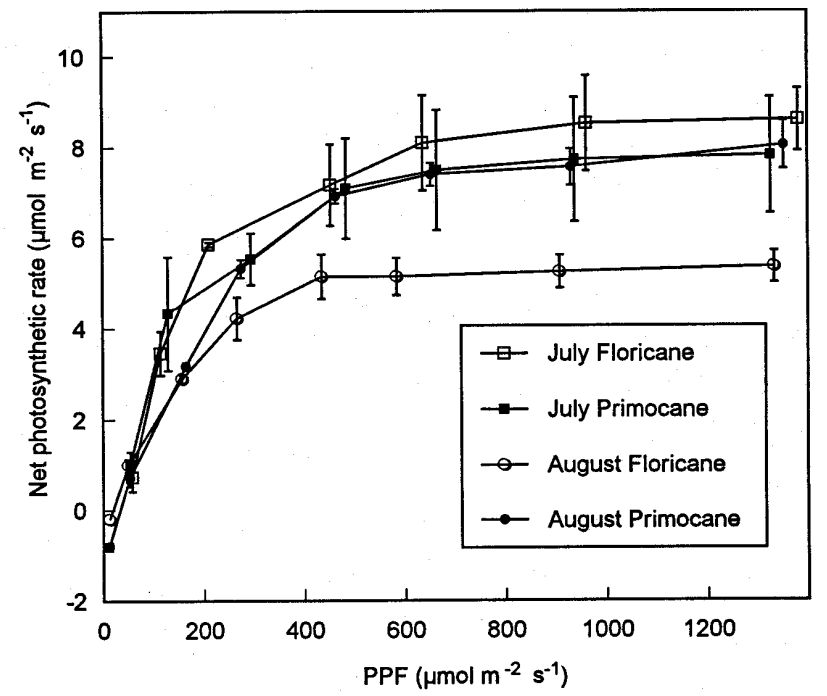

Fig. 3. Net photosynthetic rate as a function of light intensity, under steady state conditions at $25 \mathrm{C}$ and $350 \mu \mathrm{mol} \cdot \mathrm{mol}^{-1}$ external $\left[\mathrm{CO}_{2}\right]$, for 3-year-old potted 'Titan' red raspberry plants, July and August 1993 (1295-1315 and 1919-1942 growing degree-days, respectively). Data points represent means \pm sE of three leaf measurements.

Photosynthesis is one of the most temperature-sensitive factors controlling plant growth (Jones, 1992). In this study, temperatureresponse curves were generated for floricanes and primocanes after the plants had fruited, and primocane and floricane A declined geometrically as temperature increased (Fig. 4). For primocanes, the overall rate of decline was greater than for floricanes (Fig. 4). However, floricane A was lower than primocane A during the experiment, a result that, as with our light-saturation data, was likely due to leaf age. With other plants, increased respiration or a decline in the photosystem's integrity the may occur on exposure to high temperatures (Berry and Björkmann, 1980). With raspberry, this decline occurred at a lower temperature than reported for many other fruit crops (Chartzoulakis et al., 1993; Lakso and Johnson, 1990). A study of the wild raspberry, R. chamaemorus L., showed that a temperature optimum for this subarctic species was 10 to $15 \mathrm{C}$ (Marks and Taylor, 1978). These authors speculated that the physiological characteristics that enable this species to achieve maximum photosynthetic rates at low temperatures may limit its southern range. Our data suggest that $R$. idaeus also may be photosynthetically limited by warmer temperatures.

The integrated system. Three primary $\mathrm{C}$ sinks develop in the raspberry plant during the season. The fruit is a sink for $\mathrm{C}$ acquired by the floricane leaves. The movement of labeled $\mathrm{C}$ from floricanes into fruit (Fernandez and Pritts, 1993) supports this contention. A second sink is the primocane's actively growing apical meristem. Fernandez and Pritts (1993) have shown that labeled C in primocane leaves moves into the apical meristem during the early part of the growing season when growth rate is highest. A third sink is the root system. Root growth seems to be greatest during the early stages of fruiting. Carbon labeling studies suggest that primocane photosynthates move into roots, but not into floricanes, during fruiting (Fernandez and Pritts, 1993). If sink strength is proportional to growth rate, then the strong root sink may account for the decrease in primocane dry weight and RGR during fruiting. Thus, in raspberries, the greatest sink demand develops in midsummer when primocane growth is rapid, root growth is increasing, and fruiting begins.

Simultaneous with the convergence of the greatest sink demand

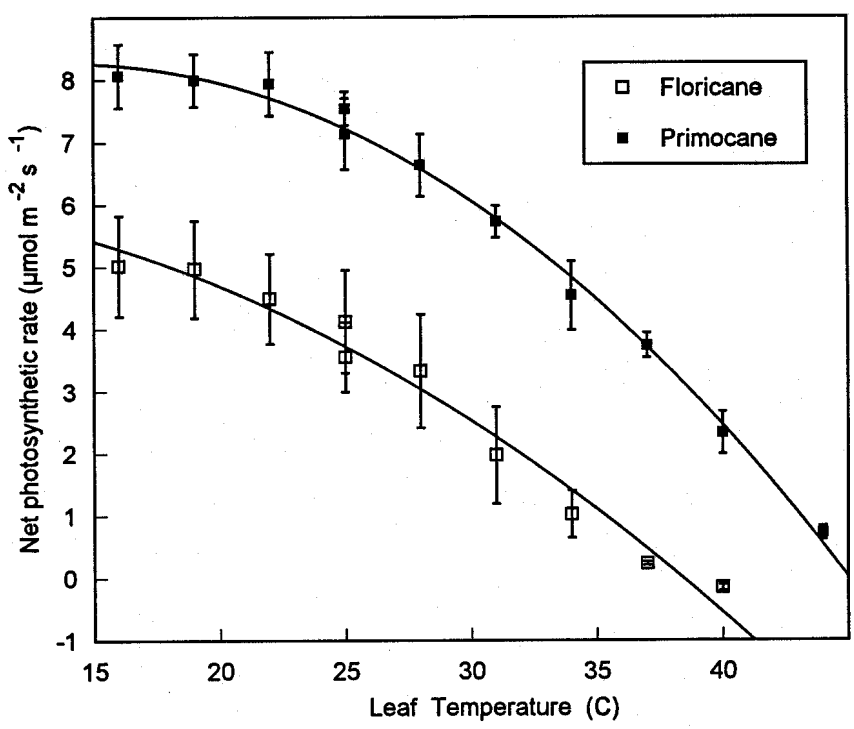

Fig. 4. Net photosynthetic rate as a function of temperature of 3-year-old potted 'Titan' red raspberry plants, taken under steady-state conditions at $350 \mu \mathrm{mol} \cdot \mathrm{mol}^{-1}$ external $\left[\mathrm{CO}_{2}\right]$, August 1993(1815-1836growing degree days). Datapoints represent means \pm sE of three leaf measurements. Second-order polynomial regressions are as follows: floricane, $\mathrm{y}=$ $-0.005 \mathrm{x}^{2}+0.016 \mathrm{x}+6.19, r^{2}=0.97^{* * * *} ;$ primocane, $\mathrm{y}=-0.009 \mathrm{x}^{2}+0.239 \mathrm{x}+6.59, r^{2}=$ $0.99^{* * * *}$.

in roots and fruit is the onset of high temperatures. 'Titan' exhibits reduced $\mathrm{A}$ at temperatures $>20 \mathrm{C}$. Presumably, leaves at the top of the canopy run an even greater risk of heat stress, and this is where most of the photosynthates and fruit are produced. Others have postulated that raspberries are sensitive to high temperatures (Hoover et al., 1989), but this was not well documented until now. Since field temperatures frequently exceed 20C, the resulting decline in A could impose an additional constraint on yield. The diurnal response that we observed in A suggests that biochemical limitations also develop at a time of day when light interception and PPF are greatest, further limiting potential yield.

Insights and implications. Many have speculated as to why raspberries do not realize their full yield potential (Braun and Garth, 1989; Dale, 1989). Realized yield is often substantially less than yield estimated from preharvest yield components (Dale, 1988; Freeman et al., 1989; Jennings and McGregor, 1989), and we found the harvest index to be only $\approx 3 \%$. Furthermore, raspberries exhibit characteristics of a source-limited plant (i.e., strong yield component compensation), despite a high leaf : fruit ratio. This is understandable when one realizes that the convergence of sink demand occurs at a time when the raspberry plant is somewhat impaired in its ability to meet this demand. Additional evidence to support a source-limited system includes the elevated yields observed with improved light conditions or primocane removal (Freeman et al., 1989; Lawson and Wiseman, 1983; Nehrbas and Pritts, 1988) and elevated $\mathrm{A}$ under a high $\mathrm{CO}_{2}$ concentration (Fernandez, 1994).

Red raspberry may be most productive under climatic conditions other than those in this study. The primary area of red raspberry production in the United States is in the Pacific Northwest. This region is characterized by a mild temperate climate, with moderate summer and winter temperatures, abundant rainfall, and a long growing season (National Oceanic Atmospheric Administration, 1985). Climates similar to this seem to be best suited for red raspberry.

The physiological characteristics of 'Titan' described herein provide explanations for several observations regarding cultivated raspberries in general. Although it is possible, and even likely, that 
other genotypes will exhibit different responses to light and temperature, the general trends we describe may still apply. Unfortunately, no other studies on cultivated raspberry have been published on which to base such comparisons. The dynamics of source-sink relationships in primocane-fruiting raspberry will be different than those of 'Titan', but both types may be intolerant to high temperatures. The subgenus Idaeobatus contains 195 species (Ourecky, 1975), so the potential amount of physiological variability is very large. Of course, this provides opportunities for improving the growth and physiological responses of cultivated germplasm through breeding.

This study suggests several other approaches that may be taken to enhance red raspberry yield. One is to improve the light interception of internal canopy leaves. Palmer et al. (1987) found that horizontally trained canopies had higher light penetration into the canopy than vertically trained canopies. Increasing floricane leaf exposure, even at the expense of primocane leaves, also may increase yield. More work is required to identify practical and effective planting and training systems that improve light interception without impeding field operations.

Another approach to increasing productivity may be to identify genotypes that show an altered pattern of fruiting or root growth, so that most root growth occurs before or after fruiting. Other approaches may inhibit root growth temporarily during fruiting, without negatively affecting long-term growth and productivity. Two of the highest yielding raspberry cultivars in the northeastern United States are 'Royalty' and 'Titan' (Pritts and Handley, 1989). 'Royalty' has a later harvest period than most other cultivars (Pritts and Handley, 1989), and the strong competition between roots and fruit may be avoided due to the lateness of harvest. 'Titan' has a long harvest period, and although strong within-plant competition occurs during the early part of harvest, root growth declines dramatically by midharvest.

Growth, acquisition, and partitioning patterns in raspberry, like in all other woody plants, are complex. There is a need to understand more clearly the control of organ development and the dynamic balance between sources and sinks before interventions can be imposed. Leaf age effects on productivity also need to be studied to determine the relative contribution of photosynthates from different leaf types over a growing season. Furthermore, studies that examine stomatal, biochemical, and feedback limitations to photosynthesis could provide useful information on novel approaches to enhance photosynthesis at the whole-plant, tissue, and cellular level. The raspberry plant is an excellent model to use for examining these fundamental relationships in woody plants.

\section{Literature Cited}

Avery, D.J. 1977. Maximum photosynthetic rate - A case study in apple. New Phytol. 78:55-63.

Ball, J.T., I.E. Woodrow, and J.A. Berry. 1987. A model predicting stomatal conductance and its contribution to the control of photosynthesis under different environmental conditions, p. 221-224. In: J. Biggens (ed.). Progress in photosynthesis research. vol. 4. Martin Nijhoff, Dordrecht, The Netherlands.

Berry, J. and O. Björkmann. 1980. Photosynthetic response and adaptation to temperature in higher plants. Annu. Rev. Plant Physiol. 28:355-377.

Boardman, N.K. 1977. Comparative photosynthesis of sun and shade plants. Annu. Rev. Plant Physiol. 31:491-543.

Braun, J.W. and J.K.L. Garth. 1989. Intracane yield compensation in the red raspberry. J. Amer. Soc. Hort. Sci. 109:526-530.

Brierley, W.G. 1931. Growth studies in the Latham raspberry. Proc. Amer. Soc. Hort. Sci. 28:182-187.

Chabot, B.F. and D.J. Hicks. 1982. The ecology of leaf life spans. Annu. Rev. Ecol. Systematics 13:229-259.
Chalmers, D.J., R.L. Canterford, P.H. Jerie, T.R. Jones, and T.D. Ugalde. 1975. Photosynthesis in relation to growth and distribution of fruit in peach trees. Austral. J. Plant Physiol. 134:169-174.

Chartzoulakis, K., I. Therios, and B. Noitaskis. 1993. Effects of shading on gas exchange, specific leaf weight and chlorophyll content in four kiwifruit cultivars under field conditions. J. Hort. Sci. 68:605-611.

Chiariello, N.R., H.A. Mooney, and K. Williams. 1991. Growth, carbon allocation and cost of plant tissues, p. 327-365. In: R.W. Pearcy, J. Ehleringer, H.A. Mooney, and P.W. Rundel (eds.). Plant physiological ecology. Chapman and Hall, New York.

Dale, A. 1988. Relationships between some yield components of the red raspberry (Rubus idaeus L.) and the fruiting season: A multivariate approach. Crop Res. (Hort. Res.). 28:123-135.

Dale, A. 1989. Productivity in red raspberries. Hort. Rev. 11:185-228.

Dawson, T.E. and L.C. Bliss. 1993. Plants as mosaics: Leaf-, ramet-, and gender-level variations in the physiology of the dwarf willow, Salix arctica. Functional Ecol. 7:293-304.

Dawson, T.E. and M.E. Geber. 1995. Genetic differences in the relative importance of stomatal and biochemical limitations to photosynthesis. Plant Cell Environ. (In press.)

Dornhoff, G.M. and R.M. Shibles. 1970. Varietal differences in net photosynthesis of soybean leaves. Crop Sci. 10:42-45.

Downton, W.J.S., W.J.R. Grant, and B.R. Loveys. 1987. Diurnal changes in the photosynthesis of field-grown grape vines. New Phytol. 105:71-80.

Fernandez, G.E. 1994. Carbon assimilation and partitioning in 'Titan' red raspberry: An analysis of canopy, whole-plant, leaf and biochemical factors. PhD diss. Cornell Univ., Ithaca, N.Y.

Fernandez, G.E. and M.P. Pritts. 1993. Growth and source-sink relationships in 'Titan' red raspberry. Acta Hort. 352:151-157.

Field, C.B. 1987. Leaf age effects on stomatal conductance, p. 367-383. In: E. Zeiger, G.D. Farquhar, and I.R. Cowan (eds.). Stomatal function. Stanford Univ. Press, Stanford.

Flinn, A.M. 1974. Regulation of leaflet photosynthesis by developing fruit in the pea. Physiol. Plant. 31:275-278.

Forshey, C.G. and D.C. Elfving. 1989. The relationship between vegetative growth and fruiting in apple trees. Hort. Rev. 11:229-287 .

Freeman, J.A., G.W. Eaton, T.E. Baumann, H.A. Daubney, and A. Dale. 1989. Primocane removal enhances yield components of raspberries. J. Amer. Soc. Hort. Sci. 114:6-9.

Fujii, J.A. and R.A. Kennedy. 1985. Seasonal changes in the photosynthetic rate of apple trees. Plant Physiol. 78:519-524.

Gutschick, V.P. 1987. A functional biology of crop plants. Croom Helm, London.

Hansen, P. 1970. ${ }^{14} \mathrm{C}$-studies on apple trees. IV. Photosynthetic consumption in fruits in relation to the leaf-fruit ratio and to the leaf-fruit position. Physiol. Plant. 23:805-810.

Hodges, J.D. 1967. Patterns of photosynthesis under natural environmental conditions. Ecology 48:234-242.

Hoover, E., J. Luby, D. Bedford, M. Pritts, E. Hanson, A. Dale, and H. Daubney. 1989. Temperature influence on harvest date and cane development of primocane-fruiting red raspberries. Acta Hort. 262:297-303.

Jennings, D.L. and G.R. McGregor. 1989. Some genetic factors which control the number and size of raspberry fruits produced on a raspberry cane, p. 315-327. In: C.J. Wright (ed.). Manipulation of fruiting. Butterworths, Boston.

Jones, H.G. 1992. Plants and microclimate: A quantitative approach to environmental plant physiology. Cambridge Univ. Press, Cambridge.

Kozlowski, T.K.,P.J. Kramer, and S.G. Pallardy. 1991. The physiological ecology of woody plants. Academic Press, New York.

Kutik, J. 1985. Chlorplast development, p. 51-75. In: Z. Sestak (ed.). Photosynthesis during leaf development. Dr. W. Junk Publishers, Boston.

Lakso, A.N. 1986. Photosynthesis in fruit trees in relation to environmental factors, p. 6-13. In: A.N. Lakso and F. Lenz (eds.). Regulation of photosynthesis in fruit trees. New York State Agr. Expt. Sta., Geneva. Lakso, A.N. and R.S. Johnson. 1990. A simplified dry matter production model for apple using automatic programming simulation software. Acta Hort. 276:141-148.

Lakso, A.N. and E.J. Seeley. 1978. Environmentally induced responses of 
apple tree photosynthesis. HortScience 13:646-650.

Landsberg, J.J., C.L. Beadle, P.V. Biscoe, D.R. Butler, B. Davidson, L.D. Incoll, G.B. James, P.J. Jarvis, P.J. Martin, R.E. Neilson, D.B.B. Powell, E.M. Slack, M.R. Thorpe, N.C. Turner, B. Warrit, and W.R. Watts. 1975. Diurnal energy, water and $\mathrm{CO}_{2}$ exchanges in an apple (Malus pumila) orchard. J. Applied Ecol. 12:659-684.

Lawson, H.M. and J.S. Wiseman. 1983. Techniques for the control of cane vigor in red raspberry in Scotland: Effects of timing and frequency of cane removal treatments on growth and yield in Glen Clova. J. Hort. Sci. 58:247-260.

Marks, T.C. and K. Taylor. 1978. The carbon economy of Rubus chamaemorous L. I. Photosynthesis. Ann. Bot. 42:165-179.

Nehrbas, S.R. and M.P. Pritts. 1988. Effect of pruning system on yield components of two summer-bearing raspberry cultivars. J. Amer. Soc. Hort. Sci. 113:314-321.

National Oceanic Atmospheric Administration 1985. Climates of the United States. Gale Research Co., Detroit.

Ourecky, D.K. 1975. Brambles, p. 98-129. In: J. Janick and J.N. Moore (eds.). Advances in fruit breeding. Purdue Univ. Press, West Lafayette, Ind.

Palmer, J.W., J.E. Jackson, and D.C. Ferree. 1987. Light interception and distribution in horizontal and vertical canopies of red raspberries. J. Hort. Sci. 62:493-499.
Pritts, M. and D. Handley. 1989. Bramble production guide. Northeast Reg. Agr. Eng. Serv., Ithaca, N.Y.

Sanford, J.C., D.K. Ourecky, and J.E. Reich. 1985. 'Titan' red raspberry. HortScience 20:1133-1134.

Sestak, Z., I. Tichá, J. Catsky, J. Solárová, J. Pospisilova, and D. Hodanova. 1985. Intergration of photosynthetic characteristics during leaf development, p. 263-286. In: Z. Sestak (ed.). Photosynthesis during leaf development. Dr. W. Junk Publishers, Boston.

Sterck, Z. and L. Ubysz. 1974. Effect of limited supply of assimilates on the relationships between their sources and acceptors. Acta Societatis Botanicorum Poloniae 43:427-445.

Vorocihinia, Z.N. 1967. The root system of raspberries. Akad. K.A. Timirjazeva 132:55-59.

Vorwinckel, T. and W.C. Oichel. 1975. The effect of climate on the photosynthesis of Picea mariana at the subarctic treeline. I. Field measurements. Can. J. Bot. 53:604-620.

Watson, M.A. 1984. Developmental constraints: Effects of population growth and patterns of resource allocation in a clonal plant (Senecio vulgaris). Amer. Naturalist 123:411-426.

Wright, C.J. 1989. Interactions between vegetative and reproductive growth, p. 15-27. In: C.J. Wright (ed.). Manipulation of fruiting. Butterworth \& Co., Boston. 